\title{
THE PARTHIAN RIVAL AND ROME'S FAILURE IN THE EAST: ROMAN PROPAGANDA AND THE STAIN OF CRASSUS
}

\begin{abstract}
Summary: The consequences of Crassus' invasion of Mesopotamia in 54-53 BCE were unanticipated and unintended; however, his disastrous failure shocked the Roman world and suddenly established the Parthians as a serious rival to Rome. Moreover, the shame the Romans felt after the Battle of Carrhae was considerable. The battle scarred the Roman psyche and severely damaged the Roman ego. This study synthesizes and investigates what became a vicious and virulent Roman literary tradition of anti-Crassus propaganda, examining how numerous Roman writers over the course of numerous centuries used the dead and disgraced Crassus as a convenient scapegoat to help explain Rome's failure to dominate the East and subdue the Parthian rival. It demonstrates that these writers ignored the legitimate causes for the First Romano-Parthian War (56 BCE - 1 CE), which Crassus had inherited, and illustrates that the disaster at Carrhae became a popular moralizing lesson about the consequences of greed, impiety, and hubris.
\end{abstract}

Key words: Rome, Parthia, Crassus, Warfare, Plutarch, Cassius Dio

On a warm, dry day in early May of 53 BCE about 45,000 Roman soldiers and auxiliaries faced a force of 10,000 battle-hardened Parthian cavalrymen across the rolling fields of Carrhae in northern Mesopotamia. The Roman commander, Marcus Licinius Crassus, who was the triumviral partner of Julius Caesar and Pompey Magnus, had been allotted an eastern command that included the responsibility of concluding the first ever open conflict between Rome and Parthia. Crassus was trying to bring a swift end to a conflict that had begun when his proconsular predecessor, Aulus Gabinius, had used the pretext of a Parthian civil conflict to involve himself in the eastern kingdom's affairs.

Crassus found himself facing the Parthian king Orodes II's most accomplished general, Surenas, near the small town of Carrhae, not far from the source of the Balikh River. This was the first time Roman and Parthian soldiers had met in a major conflict, and neither side knew what to expect. Suddenly a low and distant rumbling became 
an increasingly terrifying cacophony of drums and war cries as the Parthian army emerged from its well-placed concealed positions. Almost immediately the surprised Romans formed a defensive formation and lost the initiative in the battle. The more maneuverable and flexible Parthian cavalry relentlessly harassed the stationary Roman infantry huddled in easily fixed targets for the Parthian horse archers, and any Roman breakout attempts were met by the thunderous charge of the heavily armored Parthian cataphracts. Finally, in desperation Crassus ordered his son, Publius, with the majority of the available Roman cavalry to attack the Parthian force to drive it from the field.

At first Publius' charge appeared to have accomplished its goal as the Parthian cavalry turned and fled; however, the Romans were unaware that this "rout" was in reality a calculated feigned retreat meant to draw Publius' force away from the main Roman army so that it could be destroyed in detail. Publius unknowingly fell directly into this trap and did not recognize his vulnerable position until it was too late. The Parthians quickly surrounded and massacred Publius and about 5,000 men.

Crassus, who was busy trying to reorganize his army, had no idea that his son had committed suicide as his men were slaughtered around him until the Parthian army reappeared brandishing Publius' severed head as a war trophy. The morale of Crassus and his men plummeted as the relentless Parthian assault resumed. Completely isolated, immobile, and outgunned, the Roman army found itself corralled by the crushing charges of the Parthian cataphracts and picked apart by an endless storm of arrows. Only nightfall saved the Roman army from complete annihilation on that day.

In the battle and the subsequent retreat to Syria, Crassus lost about 30,000 men, a third of whom the Parthians captured and sent to the eastern frontier of their empire. Crassus too was a casualty of his failed expedition. In a meeting with Surenas, where the two men hoped to discuss terms for a truce, a struggle erupted and Crassus was killed. Similar to his son, Crassus' head was removed and used as a victory marker. The Parthians had demonstrated emphatically that they were a military match for the Romans. ${ }^{1}$

The consequences of Crassus' invasion were unanticipated and unintended; however, his failure shocked the Roman world and suddenly established the Parthians as a serious rival to Rome. Moreover, the shame the Romans felt after the Battle of Carrhae was considerable. The battle scarred the Roman psyche and severely damaged the Roman ego. This study synthesizes and investigates what became a vicious and virulent Roman literary tradition of anti-Crassus propaganda, examining how numerous Roman writers over the course of numerous centuries used the dead and disgraced Crassus as a convenient scapegoat to help explain Rome's failure to dominate the East and subdue the Parthian rival. It demonstrates that these writers ignored the legitimate

\footnotetext{
${ }^{1}$ For Parthian militarism and the Romano-Parthian rivalry, see OvERTOOM, N. L.: Challenging Roman Domination: The End of Hellenistic Rule and the Rise of the Parthian State from the Third to the First Centuries BCE. Baton Rouge 2016; OverToom, N. L.: The Rivalry of Rome and Parthia in the Sources from the Augustan Age to Late Antiquity. Anabasis, Studia Classica et Orientalia 7 (2016) 137-174; OverToom, N. L.: The Power-Transition Crisis of the 240s BCE and the Creation of the Parthian State. The International History Review 38.5 (2016) 984-1013; OverTooM, N. L.: The Parthians' Unique Mode of Warfare: A Tradition of Parthian Militarism and the Battle of Carrhae. Anabasis, Studia Classica et Orientalia 8 (2017).
} 
causes for the First Romano-Parthian War (56 BCE - 1 CE) that Crassus had inherited and illustrates that the disaster at Carrhae became a popular moralizing lesson about the consequences of greed, impiety, and hubris. ${ }^{2}$

\section{THE LITERARY TRADITION OF CRITICIZING ROMAN FAILURE IN THE EAST}

Most ancient and modern criticism of Crassus for conducting a major campaign against the Parthians is misplaced and results-based. ${ }^{3}$ In reality, Crassus was hardly unique or controversial in his conduct during his command prior to his defeat in the East. Several Roman generals by this period had conducted self-fulfilling and self-aggrandizing foreign campaigns that were either in the technical sense illegal or at the very least a generous overstepping of their official commands. ${ }^{4}$ The conquests of Pompey and Caesar, just to pick two corresponding examples, are remembered quite differently in our sources mainly because they were vastly successful. Yet in the case of Crassus, not only did he face contemporary opposition from the senate, which did not want another great Roman statesman to gain considerable influence at its further expense, he also

\footnotetext{
2 Plutarch finds Crassus' Carrhae campaign a suitable parallel to the disastrous Athenian invasion of Sicily by Nicias. Plut. Nic. 1. 1. Plutarch refers to the Carrhae campaign as a great blunder. Plut. Crass. 17. 4 .

${ }^{3}$ Gareth Sampson has made a recent attempt to reevaluate and recover Crassus' reputation. He argues, "For too long, the Parthians have been seen as nothing more than a one dimensional enemy whom Crassus lost to through his own incompetence; and a defeat which had little wider effect. However, such a view is merely the legacy of wounded Roman pride." SAMPSON, G. C.: The Defeat of Rome: Crassus, Carrhae and the Invasion of the East. Barnsley 2015, xvi, 56, 79-80, 83-85, 92, 95, 109-110, 169-175. Note also Marshall, B. A.: Crassus: A Political Biography. Amsterdam 1976, 143, 147-148; WARD, A. M.: Marcus Crassus and the Late Roman Republic. Columbia 1977, 1-4, 290-295; Lerouge, C.: L'image des Parthes dans le monde gréco-romain: Du début du I Ir siècle av. J.-C. jusqu'à la fin du Haut-Empire romain. Stuttgart 2007, 71. For modern bias toward Crassus, note esp. DRUMANN, W.: Geschichte Roms. Ed. P. Groebe. 2. Aufl. Bd. 4. Berlin-Leipzig 1908, 123; Heitland, W. E.: The Roman Republic. Vol. 3. Cambridge 1909, 238; GELZER, M.: Licinius Crassus (68). PWRE 13.1 (1926) 296. 7-14; CARY, M.: A History of Rome down to the Reign of Constantine. 2nd ed. London 1954, 366; FERRERO, G.: The Life of Caesar. Trans. A. E. Zimmern. New York 1962, 91; MeIER, C.: Res Publica Amissa. Wiesbaden 1966, 274-275; Grant, M.: Julius Caesar. London 1969, 44-45; CARY, M. - Scullard, H. H.: A History of Rome down to the Reign of Constantine. 3rd ed. London 1975, 243; KEAVENEY, A.: The King and the WarLords: Romano-Parthian Relations Circa 64-53 B.C. The American Journal of Philology 103.4 (1982) 423, 428; Sherwin-White, A. N.: Roman Foreign Policy in the East 168 B.C. to A.D. 1. Norman 1984, 280-281; Chahin, M.: The Kingdom of Armenia. New York 1987, 242-243; GoldsworThy, A.: Antony and Cleopatra. New Haven 2010, 105-106. In a moment of outstanding literary irony, Plutarch, who almost universally portrays Crassus negatively in the last few years of Crassus' life because of the Carrhae disaster, states in his brief comparison of Crassus to the Athenian general Nicias, "Those who have praise for Alexander's expedition, but blame for that of Crassus, unfairly judge of a beginning by its end." Plut. Nic. and Crass. 4. 5. Plutarch then continues, "But Crassus made so many blunders that he gave fortune no chance to favor him. We may not therefore wonder that his imbecility succumbed to the power of the Parthians, but rather that it prevailed over the usual good fortune of the Romans." Plut. Nic. and Crass. 5. 1.

${ }^{4}$ Gnaeus Manlius Vulso (189 BCE), Manius Aquillius (88 BCE), Lucius Licinius Murena (83 BCE), Lucius Licinius Lucullus (69 BCE), Gnaeus Pompey (65-62 BCE), Julius Caesar (58-49 BCE), and Aulus Gabinius (56-55 BCE) are all good examples.
} 
earned the harsh criticism of centuries of Roman writers. After all, Roman propaganda had every motive to distance the reputation of Rome from the disaster at Carrhae.

In late $56 \mathrm{BCE}$, prior to the appointment of Crassus to his Syrian command in $55 \mathrm{BCE}$, the Romans committed to becoming involved in an ongoing Parthian civil war, which was taking place in Mesopotamia and Media. Aulus Gabinius, the Roman governor of Syria who preceded Crassus, accepted the plea of Mithridates IV - the ousted Parthian king - for support in his civil war against his brother Orodes II. ${ }^{5}$ Although Gabinius never attacked Orodes before Crassus replaced him as governor of Syria, Gabinius' decision to intervene in the conflict officially began the First Romano-Parthian War. Yet the propagandistic literary tradition surrounding Crassus almost universally ignores the fact that Gabinius already had committed Rome to a Parthian war before Crassus' appointment to his Syrian command and disregards that Crassus actually had every reason to pursue this legitimate conflict and end it during his command in the East. Since in reality Crassus inherited an ongoing and legitimate conflict, it was Crassus' failure and particularly his death that made the anti-Crassus propagandistic tradition possible. Let us discuss some of the examples of this tradition so that we may recognize this biased and unrealistic depiction of Crassus and his campaign.

The Romans in general found military defeat in the East unacceptable and blamed such setbacks on their unfortunate generals. The greedy, violent, or irreligious Roman commander, who was weak of character and who eventually failed in the East, was a common literary trope. For instance, there are the accounts of the failure and death of Manius Aquillius, who was a commander in Asia Minor during the First Mithridatic War, in 88 BCE. ${ }^{6}$ Then there are the accounts of Lucius Licinius Lucullus, whom the sources criticize for his inability to end the conflict against Mithridates VI and Tigranes II in the early 60 s BCE. $^{7}$ Similarly, the sources criticize Gabinius for his actions in the East from $57-55$ BCE. ${ }^{8}$ Note also how the sources offer praise of Publius Ventidius Bassus for his defense of Syria against the Parthians in the early 30s BCE and contrast that praise with criticism of Mark Antony's envy and his military failures in the East only a couple of years later. ${ }^{9}$ Moreover, there is the tradition of the ineptitude of the general Lucius Caesennius Paetus in Armenia, which led to the Roman disaster at Rhandeia in $62 \mathrm{CE} .^{10}$

Roman emperors were not immune to harsh criticism of unsuccessful actions in the East or failed eastern policy. Later Roman writers blamed Hadrian's envy of Trajan's success against the Parthians for his abandonment of Trajan's eastern gains and criticized Hadrian for his weakness in making this decision. ${ }^{11}$ Later Roman writers also indirectly associated the inappropriate boasting and military shortcomings of

${ }^{5}$ Note Appian Syr. 8. 51; Dio 39. 56. 2; Jos. Ant. 14. 98; Jos. Bell. 1. 175; Justin 42. 4. 1-4.

${ }^{6}$ Appian Mithr. 3. 21; 16. 112; Pliny 33. 14. 48; 47. 134; Athen. 5. 50; Diod. 37. 26-27; Vell. Pat. 2. 18; Cic. Man. 4. 11; Cic. Tusc. 5. 5, 14.

${ }^{7}$ Dio 36. 2. 1-2; 14. 4 - 15. 1; 17. 1, 46; 37. 7. 1; Appian Mithr. 13. 90; Plut. Luc. 35-36.

${ }^{8}$ Appian Syr. 8. 51; Cic. Prov. 9-11; Cic. Pis. 41-43; 48-52; Cic. Sest. 93.

${ }^{9}$ Plut. Ant. 30, 33-35, 38-50; Dio 49. 19-21; Florus 2. 19-20. Note Lerouge (n. 3) 310-313.

10 Tac. Ann. 15. 1-17, 24; Dio 62. 21. See also Orosius 7. 7.

${ }^{11}$ Ruf. Fest. 14. 4-5; 20. 3; Eutrop. 8. 3. 
Caracalla in the East, fighting against the Parthians, with Crassus' disaster at Carrhae. ${ }^{12}$ Macrinus, too, found censure for his failures in the East. ${ }^{13}$ Further, Herodian considered Severus Alexander's policy in the East weak and unsuccessful, which led Herodian to compare Severus Alexander's missteps to the defeats of Crassus and Antony. ${ }^{14}$

There was criticism of Philip the Arab's arrogance in the East. ${ }^{15}$ Roman writers found the humiliating defeat and capture of Valerian near Edessa in $260 \mathrm{CE}$ unacceptable. ${ }^{16}$ Roman writers also juxtaposed the shameful actions of Gallienus in the East with the decisive actions of the king of Palmyra, Odaenathus. ${ }^{17}$

Even emperors who initially had found success in the East endured reproach once their endeavors lost momentum. Aurelius Victor describes Carus, who briefly captured the old Parthian capital, Ctesiphon, in $283 \mathrm{CE}$, as a successful leader until he became too reckless in the East and ignored divine warnings. ${ }^{18}$ Further, there is a tradition of criticizing Julian, whose apparent violent desire for glory overwhelmed him and made him overlook the "numerous presages through which he was being forbidden to attack Persia." 19 Finally, there was almost universal criticism of Jovian's humiliating eastern concessions, following Julian's sudden death on the battlefield in Mesopotamia. ${ }^{20}$

With all of these examples in mind, an important characteristic of the Roman literary tradition that developed around the longstanding Roman rivalry with the Arsacid Parthians and Sassanid Persians was the Romans' unwillingness to accept their own military and imperial limitations in the East. In this tradition, failure in the East was the result of poor leadership and moral character, not a deficiency of the Roman army or state. Numerous Roman statesmen found their legacies marred by criticism of their shortcomings in the East; however, Crassus became the most popular example.

\section{THE ANTI-CRASSUS PROPAGANDISTIC TRADITION}

Roman writers developed and utilized two primary literary tropes to dismantle the reputation of Crassus for centuries in order to explain his missteps in the East and to absolve the Roman state of his failure: Crassus' alleged insatiable greed and his alleged

${ }^{12}$ HA Carac. 6. 4-6; Herodian 4. 11, 13-14; Orosius 7. 18. See also Dio 78. 3-5; Ruf. Fest. 21. 3; Eutrop. 8. 20; Orosius 7. 18. Note HeKSTER, O. - KAIZER, T.: An Accidental Tourist? Caracalla's Fatal Trip to the Temple of the Moon at Carrhae/Harran. Ancient Society 42 (2012) 89-107.

${ }^{13}$ Dio 78. 26. 2 - 27. 2; Herodian 4. 15; HA Macr. 8.

${ }^{14}$ Herodian 6. 5-6; 8. 3.

${ }^{15}$ HA Gord. 29. 1; 30.1.

${ }^{16}$ Ruf. Fest. 23. 1; Eutrop. 9. 7; Aur. Vic. Epit. Caes. 32; Orosius 7. 22; Lact. Mort. Pers. 5, 9; Zos. 1. 20. Note also HA Valer. 1. 1 - 4. 4.

${ }^{17}$ HA Gall. 10. 1-3; 12. 1, 6; 13. 4-5; HA Tyrranni 15; 30. 6; HA Valer. 4; Orosius 7. 22.

18 Aur. Vic. Caes. 38. Rufus Festus records that the "Celestial Divinity" became jealous of Carus' success against the Persians and, therefore, struck him down with lightning. Ruf. Fest. 24. 2. Note also Eutrop. 9. 18-19.

${ }^{19}$ Aur. Vic. Epit. Caes. 43. 8. See also Amm. Mar. 23. 2; 5. 4; Ruf. Fest. 28; Eutrop. 10. 16; Orosius 7. 30. Orosius portrays Theodosius I as an avenger of Julian. Orosius 7. 34.

${ }^{20}$ Ruf. Fest. 29; Eutrop. 10. 17; Amm. Mar. 25. 7. Note also Orosius 7. 31. 
hubristic irreverence. The harsh criticisms of later Roman statesmen and emperors for their failures in the East in many ways originated in the anti-Crassus propagandistic tradition that emerged in the post-Carrhae Roman world. Yet no other Roman statesman became the victim of such a popular and universally critical literary tradition.

The initial problem that the image of Crassus faced was that both he and his well-respected son, Publius, died during the Carrhae campaign. Thus, Crassus died without an apologist to take up his cause; however, his subordinate, Cassius, who was highly critical of Crassus' failure, survived the conflict. It is highly likely that Cassius wrote a report of the campaign that portrayed himself flatteringly and blamed the failure on Crassus. ${ }^{21}$ This biased initial framing of the conversation about the Carrhae campaign heavily influenced the later anti-Crassus tradition. For example, Plutarch records,

But now, contrary to their hopes [of swift victory], they [the Roman soldiers] were led to expect a struggle and great peril. Therefore, some of the officers thought that Crassus ought to call a halt and reconsider the whole undertaking. Among these was Cassius, the quaestor. The seers, also, quietly let it become known that the omens for Crassus, which came from their sacrifices, were always bad and inauspicious. But Crassus paid no heed to them, nor to those who advised anything else except to press forward. ${ }^{22}$

Here we see that in this portrayal of events Cassius offered good advice, which the impious, careless, and brash Crassus ignored. Plutarch also argues that Cassius gave sound advice that Crassus ignored on several other occasions, and Plutarch portrays Cassius as brave and decisive in battle while Crassus appears mostly weak and hesitant. ${ }^{23}$ Yet Plutarch is not the only offender. For example, Appian states, "Thus in a marvelous manner Cassius came into possession of twelve first-rate legions, to whom were added a certain number of Parthian mounted bowmen, who were attracted by the reputation he had acquired among them from the time when, as quaestor to Crassus, he had shown himself to be more skillful than that general." 24 Meanwhile, a simultaneous tradition developed that portrayed Cassius as a savior and avenger of Rome. For instance, Vellius Paterculus argues, "Remnants of the legions were saved by Gaius Cassius - (he was later the perpetrator of a most atrocious crime, but was at that time quaestor) - who not only retained Syria in its allegiance to the Roman people, but succeeded, by a fortunate issue of events, in defeating and putting to rout the Parthians when they crossed its borders." ${ }^{25}$ Moreover, previously in this section Velleius blames

${ }^{21}$ WARD (n. 3) 295 n. 25; SHERWIN-White (n. 3) 281.

22 Plut. Crass. 18. 4-5. See also Plut. Crass. 17. 6; 19. 3-6.

${ }^{23}$ Plut. Crass. 20. 2; 22. 4; 23. 3, 5; 27. 5; 28. 3-5. See also Dio 40. 26-29. Plutarch also emphasized Crassus' old age as a handicap. Plut. Crass. 17. 1-2; 18. 1; 19. 6.

${ }^{24}$ Appian $B C$ 4. 59. See also Dio 47. 30. 3.

25 Vell. Pat. 2. 46. 4. Note also Cic. Phil. 11. 14; Plut. Brut. 7. 3; 43. 7-8; Jos. Ant. 14. 119; Jos. Bell. 1. 180-182; Livy Epit. 108. 2; Orosius 6. 13. Justin's account is slightly less flattering to Cassius. Justin 42. 4. 5. 
Crassus' failure on his lustfulness for gold and glory and wishes that only Crassus had died in the East because, as Velleius peculiarly claims, Crassus' death in isolation would have been advantageous to the Roman state. ${ }^{26}$

As touched upon by Velleius, Roman writers especially emphasized the vices of greed and impiety to emphasize the apparent moral weakness of Crassus. Josephus connected Crassus' violation of the temple of Jerusalem and his looting of its wealth directly to the destruction of his army and his death. ${ }^{27}$ Pliny the Elder writes,

M. Crassus, a member of the same family, used to say that no man was rich, who could not maintain a legion upon his yearly income. He possessed in land two hundred millions of sesterces, being the richest Roman citizen next to Sulla. Nor was even this enough for him, but he must want to possess all the gold of the Parthians too! And yet, although he was the first to become memorable for his opulence - so pleasant is the task of stigmatizing this insatiate cupidity - we have known of many manumitted slaves, since his time, much more wealthy than he ever was. ${ }^{28}$

Meanwhile, Dio records,

But Crassus, desiring for his part to accomplish something that involved glory and at the same time profit, and seeing that no such thing was possible in Syria, where the people themselves were quiet, and those who had formerly warred against the Romans were by reason of their powerlessness causing no disturbance, made a campaign against the Parthians. He had no complaint to bring against them nor had the war been assigned to him; but he heard that they were exceedingly wealthy and expected that Orodes would be easy to capture, because he was but newly established. ${ }^{29}$

Furthermore, Dio later offers a tale that the Parthians poured gold down Crassus' throat, stating, "And the Parthians, as some say, poured molten gold into his mouth in mockery; for though a man of vast wealth, he had set so great store by money as to pity those who could not support an enrolled legion from their own means, regarding them as poor men." ${ }^{30}$ Florus too records this tale, declaring, "The head of Crassus was cut off and with his right hand was taken back to the [Parthian] king and treated with mockery which was not undeserved; for molten gold was poured into his gaping mouth, so that the dead and bloodless flesh of one whose heart had burned with lust for gold was itself burnt with gold." ${ }^{11}$ Meanwhile, Plutarch states,

${ }^{26}$ Vell. Pat. 2. 46. 2-3.

${ }^{27}$ Jos. Bell. 1. 179; Jos. Ant. 14. 105-109, 119.

${ }^{28}$ Pliny NH 33. 47. 134. See also Plut. Crass. 1. 2; 2. 1; 6. 5-7; 14.4.

${ }^{29}$ Dio 40. 12. 1.

${ }^{30}$ Id. 40. 27. 3.

${ }^{31}$ Florus 1. 46. 10. 
Now my own opinion is that the harm Lucullus did his country through his influence upon others, was greater than the good he did her himself. For his trophies in Armenia, standing on the borders of Parthia, and Tigranocerta, and Nisibis, and the vast wealth brought to Rome from these cities, and the display in his triumph of the captured diadem of Tigranes, incited Crassus to his attack upon Asia; he thought that the Barbarians were spoil and booty, and nothing else. It was not long, however, before he encountered the Parthian arrows, and proved that Lucullus had won his victories, not through the folly and cowardice of his enemies, but through his own daring and ability. ${ }^{32}$

Plutarch here emphasizes Crassus' foolishness and greediness. He also, on the one hand, finds Lucullus' incomplete command in the East regrettable but, on the other hand, praises Lucullus' generalship at Crassus' expense, even though Lucullus never encountered the Parthians in combat. ${ }^{33}$

Certainly, Crassus stood to gain great wealth and fame if he defeated Parthia; however, his primary motivation was political advancement at Rome. ${ }^{34}$ A successful major military command had eluded Crassus. The military successes of Pompey in Spain and Lucullus in Anatolia had overshadowed Crassus' efforts against Spartacus in the late $70 \mathrm{~s} \mathrm{BCE} .{ }^{35} \mathrm{By} 55 \mathrm{BCE}$ Crassus wanted and needed to elevate his political standing in response to his growing rivalry with Pompey and the recent military successes of Pompey and Caesar. The war against Parthia provided him with this opportunity. ${ }^{36}$ Therefore, the accumulation of military glory and wealth in the East was a means to an end, not the primary aim of Crassus' command itself. ${ }^{37}$ If Crassus could have satisfied his political ambitions at Rome without a major war against Parthia, he likely would have done so since his lack of a military command in over fifteen

${ }^{32}$ Plut. Luc. 36. 6-7. See also id. Crass. 1. 2; 2. 1-2; 6. 5-7, 14. 4. For an account of the wealth Lucullus brought back to Rome, note id. Luc. 37. 3-4.

${ }^{33}$ Note Plut. Luc. 36. 5-6. Here we find a good example of Plutarch's rhetorical agenda in his moralistic lives. Plutarch meant for Lucullus to be a hero and for Crassus to be a cautionary tale. At the end of his depiction of Lucullus, Plutarch exaggerates his victory over Mithridates VI and Tigranes II and concludes that the gods considered him "noble" and "god-like." Plut. Cim. and Luc. 3. 3-6. This certainly contrasts with the depiction of Crassus as impious and cursed by the gods. Note Plut. Nic. and Crass. 5. 2.

${ }^{34}$ Florus is the only source that argues that Crassus took up the command in Syria because he was "eager for power (potentiae)." Yet he still argues that the prospect of more riches was the main motivation for Crassus. Florus 2. 13. 10-12. WARD (n. 3) 281; SEAGER, R.: Pompey the Great: A Political Biography. Malden 2002, 118-119.

${ }^{35}$ Although Crassus served as consul alongside Pompey in 70 BCE, following the end of the Third Servile War, the people of Rome celebrated the military victories of Pompey. In fact, Crassus did not earn a triumph for his victory in the war; instead, he had to settle for a public ovation. Pompey became the leading man in Rome. Plut. Crass. 11. 7-12. 2; Appian BC 1. 120-121.

36 WARD (n. 3) 281-282, 286-287, 293; BRUnT, P. A.: The Fall of the Roman Republic and Related Essays. Oxford 1988, 83; LEROUGE (n. 3) 75.

${ }^{37}$ This concept of not confusing the rewards of conquest with its actual motives of course runs parallel with the larger societal attitudes and motives of the Romans in war. See esp. GRUEN, E. S.: The Hellenistic World and the Coming of Rome. 2 vols. Berkeley - Los Angeles 1984, 314. 
years demonstrates that Crassus was not particularly interested in warfare; however, the prospects of a Parthian expedition were too favorable in 55/54 BCE to overlook. Since Crassus had inherited the war, he was justified to pursue it. Moreover, the Roman alliance with Mithridates IV against Orodes II provided Crassus with a clear cause for war and made Parthia appear vulnerable, which made Crassus confident, perhaps overly confident, that he could quickly achieve his military and political goals against the Parthians. ${ }^{38}$ By portraying Crassus as blinded by greed, Roman writers could overlook the political and military realities that Crassus faced in 55-53 BCE, which heavily influenced his decision to invade Mesopotamia, namely his political need to respond to the growing power and influence of Pompey and Caesar through a successful military campaign and the military need of the Roman state to conclude the open-ended war against the Parthians begun by Gabinius in 56 BCE. Instead, Roman writers could present Crassus' moral failings of insatiable greed and hubristic irreverence as the "true" motivation behind and "true" explanation of Crassus' failed campaign against the Parthians and thus protect the image of Rome.

Dionysius of Halicarnassus emphasizes Crassus' impiety, stating, "But the most remarkable and the greatest instance [of impiety] happened in my time when Licinius Crassus, a man inferior to no commander of his age, led his army against the Parthian nation contrary to the will of Heaven and in contempt of the innumerable omens that opposed his expedition." ${ }^{39}$ Florus in his summary of Crassus' Parthian expedition similarly records,

While in the north the Roman people by the hand of Caesar were conquering the Gauls, in the east they received a serious blow from the Parthians. Nor can we complain of fortune; for it was a disaster which admitted of no consolation. Both gods and men were defied by the avarice of the consul Crassus, in coveting the gold of Parthia, and its punishment was the slaughter of eleven legions and the loss of his own life. For Metellus, the tribune of the people, had called down terrible curses on the general as he was leaving Rome; and after the army had passed Zeugma, the Euphrates swallowed up the standards, which were swept away by its swirling eddies; and when Crassus had pitched his camp at Nicephorium, ambassadors arrived from King Orodes with a message bidding him remember the treaties made with Pompeius and Sulla. Crassus, who coveted the royal treasures, answered not a word that had any semblance of justice, but merely said that he would give his reply at Seleucia. The gods, therefore, who punish those who violate treaties, did not fail to support either the craft or the valor of our enemies. ${ }^{40}$

\footnotetext{
${ }^{38}$ In fact, Plutarch tells us that Caesar "wrote to him from Gaul approving of his project, and inciting him on to the war." Plut. Crass. 16. 3. Ward argues that Caesar hoped a victorious Crassus could help balance against Pompey's power at Rome. WARD (n. 3) 282.

${ }^{39}$ Dion. Hal. 2. 6. 4. See also Val. Max. 1. 6. 11.

${ }^{40}$ Florus 1. 46. 1-6.
} 
Appian also blends the two vices of greed and impiety together in his account, arguing,

Crassus took Syria and the adjacent country because he wanted a war with the Parthians, which he thought would be easy as well as glorious and profitable. But when he took his departure from the city there were many unfavorable omens, and the tribunes forbade the war against the Parthians, who had done no wrong to the Romans. As he would not obey, they invoked public imprecations on him, which Crassus disregarded; wherefore he perished in Parthia, together with his son of the same name and his army, not quite 10,000 of whom, out of 100,000, escaped to Syria. The disaster of Crassus will be described in my Parthian history. ${ }^{41}$

These examples further illustrate that the anti-Crassus propagandistic tradition blamed the cause of the war on Crassus' greed and blamed the result of the war on his irreverence.

Unsurprisingly, Plutarch offers the most dramatic account of Crassus departing Rome on his way to Syria. Plutarch claims that, when the command of Syria fell to Crassus by lot, Crassus' personality suddenly changed as he began to fantasize eagerly about conquering the entire Parthian Empire. ${ }^{42}$ Plutarch also claims that, because Crassus had no authority or cause for war against the Parthians, Gaius Ateius Capito planned to block his departure from Rome. ${ }^{43}$ Plutarch states,

But Ateius, on meeting Crassus, at first tried to stop him with words, and protested against his advance; then he bade his attendant seize the person of Crassus and detain him. And when the other tribunes would not permit this, the attendant released Crassus, but Ateius ran on ahead to the city gate, placed there a blazing brazier, and when Crassus came up, cast incense and libations upon it, and invoked curses which were dreadful and terrifying in themselves, and were reinforced by sundry strange and dreadful gods whom he summoned and called by name. The Romans say that these mysterious and ancient curses have such power that no one involved in them ever escapes, and misfortune falls also upon the one who utters them, wherefore they are not employed at random nor by many. And accordingly at this time they found fault with Ateius because it was for the city's sake that he was angered at Crassus, and yet he had involved the city in curses which awakened much superstitious terror. ${ }^{44}$

Plutarch's account is almost entirely theatrical fiction, which blames Crassus' delusions and desires for the war and which has Crassus leave Rome under a cloud of ill forebod-

${ }^{41}$ Appian BC 2. 18.

${ }^{42}$ Plut. Crass. 16. 1-2.

${ }^{43}$ Plut. Crass. 16. 3.

${ }^{44}$ Plut. Crass. 16. 4-5. Plutarch found Crassus' role in death equally theatrical. Note Plut. Crass. 33. See also Polyaen. 7. 41. Pliny also argues that Crassus ignored a terrible omen. Pliny 15. 21. 
ing. Meanwhile, Cicero, who was a contemporary of these events, offers a much less theatrical version. He records that his brother Quintus said,

'We see what happened to Marcus Crassus when he ignored the announcement of unfavorable omens. It was on the charge of having on this occasion falsified the auspices that Gaius Ateius, an honorable man and a distinguished citizen, was, on insufficient evidence, stigmatized by the then censor Appius, who was your associate in the augural college, and an able one too, as I have often heard you say. I grant you that in pursuing the course he did Appius was within his rights as a censor, if, in his judgement, Ateius had announced a fraudulent augury. But he showed no capacity whatever as an augur in holding Ateius responsible for that awful disaster which befell the Roman people [at Carrhae]. Had this been the cause then the fault would not have been with Ateius, who made the announcement that the augury was unfavorable, but with Crassus, who disobeyed it; for the issue proved that the announcement was true, as this same augur and censor admits. But even if the augury had been false it could not have been the cause of the disaster; for unfavorable auguries - and the same may be said of auspices, omens, and all other signs - are not the causes of what follows: they merely foretell what will occur unless precautions are taken. Therefore Ateius, by his announcement, did not create the cause of the disaster; but having observed the sign he simply advised Crassus what the result would be if the warning was ignored. It follows, then, that the announcement by Ateius of the unfavorable augury had no effect; or if it did, as Appius thinks, then the sin is not in him who gave the warning, but in him who disregarded it. ${ }^{95}$

Quintus here still blames the disaster at Carrhae entirely upon Crassus for ignoring the "unfavorable augury"; however, there is no mention here or in Cicero's letter that discusses Crassus' departure from Rome of a public standoff between Ateius and Crassus at the gates of Rome. This disparity between Cicero and Plutarch's accounts led Sampson to conclude recently, "Again we see that the later ancient sources were all too eager to add dramatic elements to the story, especially one that made the defeat seem inevitable." ${ }^{46}$ Indeed, the anti-Crassus tradition is quite dramatic, even in its early stage soon after the battle.

Cicero's recorded discussion with his brother in 44 BCE is our earliest surviving evidence that the Romans used Crassus' alleged impiety to discredit Crassus and to explain his failure, and in fact, the Romans quickly accepted the inevitability of Crassus' failure because of his moral failings. Cicero states, "Passing by men of earlier day, let us take Marcus Crassus. What advantage, pray, do you think it would have been to him, when he was at the very summit of power and wealth, to know that he was destined to perish beyond the Euphrates in shame and dishonor, after his son had been

\footnotetext{
${ }^{45}$ Cic. De Div. 1. 29-30.

${ }^{46}$ SAMPSON (n. 3) 97.
} 
killed and his own army had been destroyed?"47 Moreover, Dio claims much later that after Crassus ignored innumerable bad omens his soldiers despaired and feared certain death, concluding, "At any rate, in all else that they did also, as if predestined to ruin by some divinity, they were helpless in both mind and body." 48 By focusing on Crassus' irreverence and placing the defeat in the hands of destiny, later Roman writers could try to rid the Roman army and state of responsibility for the inevitable disaster at Carrhae. Thus, we see how total censure of Crassus' moral character helped free the Romans psychologically from his military failure.

Such brutal criticism of Crassus demonstrates the extremeness of the anti-Crassus propagandistic tradition, which remained popular into late antiquity and beyond. ${ }^{49}$ For instance, Julian in the middle fourth century CE states, "I need not now remind you of ancient history, of Antony and Crassus, who were generals with the fullest powers, or tell how after long-continued dangers we succeeded in wiping out the disgrace they incurred, and how many a prudent general retrieved their blunders." ${ }^{50}$ Meanwhile, Eutropius remarks,

About the same time, in the six hundred and ninety-seventh year from the foundation of the city, Marcus Licinius Crassus, the colleague of Cnaeus Pompey the Great in his second consulship, was sent against the Parthians; and having engaged the enemy near Carrhae, contrary to the omens and auspices, was defeated by Surena, the general of king Orodes, and at last killed, together with his son, a most noble and excellent young man. The remains of the army were saved by Caius Cassius the quaestor, who, with singular courage, so ably retrieved the ruined fortune of the Romans, that, in his retreat over the Euphrates, he defeated the Persians [that is, the Parthians] in several battles. ${ }^{51}$

${ }^{47}$ Cic. De Div. 2. 22. Soon after Cicero argues that Crassus surely would not have crossed the Euphrates if he knew the future. Cic. De Div. 2. 24. Later, Cicero remarks "When Marcus Crassus was embarking his army at Brundisium a man who was selling Caunian figs at the harbor, repeatedly cried out 'Cauneas, Cauneas.' Let us say, if you will, that this was a warning to Crassus to bid him 'Beware of going,' and that if he had obeyed the omen he would not have perished. But if we are going to accept chance utterances of this kind as omens, we had better look out when we stumble, or break a shoe-string, or sneeze!" Cic. De Div. 2. 84. Cicero concludes, "I recall a multitude of prophecies which the Chaldeans made to Pompey, to Crassus and even to Caesar himself (now lately deceased), to the effect that no one of them would die except in old age, at home and in great glory. Hence it would seem very strange to me should anyone, especially at this time, believe in men whose predictions he sees disproved every day by actual results." Cic. De Div. 2. 99. Thus, Cicero casts serious doubts upon the reliability of divination; however, his arguments demonstrate that some Romans believed that Crassus had been warned by divinity and that by ignoring these warnings Crassus had sealed his fate.

${ }^{48}$ Dio 40. 17-19.

${ }^{49}$ Note the Byzantine chronicler George Syncellus' discussion of Crassus's failure and Cassius' bravery in his ninth century CE work, The Chronogrophy. Note also Zos. 3. 23. 2; Hieron. Chron. 181.

${ }^{50}$ Julian Or. 1. 17D.

${ }^{51}$ Eutrop. 6.18. 
Although Eutropius appears to be one of the only Roman writers who acknowledges that Crassus "was sent against the Parthians (contra Parthos missus est)", he still blames Crassus' impiety and stubbornness for his failure and presents Cassius as an avenging savior. ${ }^{52}$ Moreover, Rufus Festus records,

Crassus himself - when, after he had been enticed to a parlay, he was nearly captured alive - had escaped while his tribunes resisted, and, seeking flight, was killed. His severed head, with his right hand, were borne to the [Parthian] king and then maintained for sport, so that molten gold might be poured into his throat: to wit, in order that he who, burning with lust for plunder, after he had been asked by the king to grant peace, had declined, flames of gold might consume his remains even after he perished. Lucius Cassius, Crassus' quaestor, a vigorous man, gathered the remains of the scattered army. Against the Persians [that is, the Parthians], who were rushing toward Syria, he thrice contended in most admirable fashion and, after they had been repelled across the Euphrates, he ravaged them. ${ }^{53}$

Here Rufus Festus emphasizes Crassus perishing while trying to flee and stresses the punishment of Crassus even after death for his reckless aggression and avarice. Moreover, once again Cassius appears in another account as an avenging savior. Finally, note Orosius, who in the early fifth century CE wrote,

In the six hundred and ninety-seventh year of the City, Crassus, who shared the consulship with Pompey, obtained by lot the command against the Parthians. He was a man of insatiable cupidity. When he heard of the riches of the Temple at Jerusalem that Pompey had left untouched, he turned aside to Palestine and came to Jerusalem, where he entered the Temple and plundered its treasures. Thence directing his course to Parthia he requisitioned auxiliaries from the allied states, wherever his march led, and exacted tribute. As soon as he had crossed the Euphrates, he met Vageses, who had been sent as an envoy by Orodes, the king of the Parthians. Vageses violently reproached the Roman for being led by avarice to cross the Euphrates contrary to the terms of the treaty of Lucullus and Pompey. He predicted that on account of this he would soon be burdened with Chinese iron instead of with Parthian gold. ${ }^{54}$

${ }^{52}$ Note also Vell. Pat. 2. 46. 2; Plut. Pomp. 52. 3; Livy Epit. 105. 3; Orosius 6. 13. One Roman writer wrote, "The senate that gave laws to the tribes of the East, and the senate that dared to attack the Parthians - and would have conquered them, too, had not the fortune of Rome just then assigned our army so covetous a leader [Crassus]." HA Clod. 13. 6. This Roman author here puts forth the argument that the Roman Senate planned to conquer the Parthians. Therefore, the war was not Crassus' idea; however, his covetousness turned the war into a disaster and ended Rome's ability to subdue the Parthians.

${ }^{53}$ Ruf. Fest. 17. 2-4.

${ }^{54}$ Orosius 6. 13. 
Here again, according to Orosius, Crassus' lust for riches drove him to war and blinded him to danger. Orosius soon after concludes,

When this disaster of the Romans became known, many provinces of the East would have withdrawn from the alliance and protection of the Roman people, had not Cassius, after collecting a few of the soldiers who had fled, exercised exceptional spirit, courage, and moderation, and thus restrained Syria, which was then in revolt. Cassius killed Antiochus and defeated his mighty forces in a battle. He also fought the Parthians who had been dispatched by Orodes into Syria and who had recently entered Antioch. He drove them off and slew their leader, Osages. ${ }^{55}$

Orosius here exaggerates the dangers facing Cassius and his accomplishments in order to uphold the tradition of Cassius saving the Romans in the East and avenging Crassus' blunder. Thus, we find ample evidence of a dramatic and propagandistic literary tradition that developed quickly and had a lasting influence concerning the role of Cassius and Crassus in the Carrhae campaign, where, although they were both Romans fighting the Parthians, Cassius emerged as the protagonist and Crassus emerged as the antagonist. ${ }^{56}$ The Roman writers made it abundantly clear with whom the Roman audience was supposed to empathize and support.

\section{THE PARTHIAN RIVAL AND ROME'S DESIRE FOR VENGEANCE IN THE POST-CARRHAE WORLD}

With the catastrophe of Crassus' invasion, Rome failed in its initial attempt to establish unrivaled world empire, and Parthia suddenly emerged as a direct and legitimate threat to Roman hegemony. The costly but unsuccessful major military conflicts between the Romans and Parthians in the 40s-30s BCE helped solidify the new rivalry. Augustus found another costly invasion of Parthia unappealing and looked to a possible diplomatic solution to the Parthian problem. Augustan Age writers especially villainized Crassus in order to reinforce Augustan imperial propaganda concerning the new Roman relationship with the Parthians, which claimed that Augustus was the avenger of Crassus. For example, although he is a much later writer, Dio illustrates well how Augustus put this propaganda into action during his reign. Dio records,

Meanwhile Phraates [IV], fearing that Augustus would lead an expedition against him because he had not yet performed any of his engagements, sent back to him the [Roman] standards and all the captives, with the exception of a few who in shame had destroyed themselves or, eluding detection,

55 Orosius 6. 13.

${ }^{56}$ Note also V Maccabees 41. 16-17, which dubiously claims Cassius avenged Crassus' defeat by reclaiming Mesopotamia. 
remained in the country. Augustus received them as if he had conquered the Parthian [king] in a war; for he took great pride in the achievement, declaring that he had recovered without a struggle what had formerly been lost in battle. Indeed, in honor of this success he commanded that sacrifices be decreed and likewise a temple to Mars Ultor [that is, Mars the Avenger] on the Capitol, in imitation of that of Jupiter Feretrius [that is, Jupiter of Retribution], in which to dedicate the standards; and he himself carried out both decrees. Moreover, he rode into the city on horseback and was honored with a triumphal arch. ${ }^{57}$

Augustus' diplomatic policy was a political risk because his avoidance of a military solution in the East potentially made Rome and his regime appear weak. However, Augustus was a masterful statesman, who used his imperial propaganda to manipulate the public perception of his nonviolent eastern policy against the Parthians.

Augustus eagerly portrayed his diplomatic victory over Phraates IV in 20 BCE as an actual military victory over the Parthians, and it is telling that Augustus associated the returned standards of Crassus with his new temple to Mars the Avenger. Further, Augustus' most famous surviving statue, the Augustus of Prima Porta, portrays a youthful Augustus as a victorious imperator or commander in armor and military clothing, holding a consular baton and raising his right hand to address his triumphant soldiers, while Cupid, who is riding a dolphin and attempting to tug at Augustus' toga, illustrates Augustus' alleged familial connection to Venus. ${ }^{58}$ Augustus' breastplate contains personifications of various defeated peoples and of the gods of the sky and earth. Yet the centerpiece of his breastplate is an image of a bearded Parthian, perhaps Phraates IV, surrendering a Roman legionary eagle to a Roman commander, perhaps Tiberius, who received the standards, or the personification of Mars Ultor, whom Augustus favored, or even the personification of Roma, flanked by an aggressive hound. Therefore, this statue was supposed to be a very public visual representation of Augustus" "triumph" in the East over the Parthians and the establishment of Roman hegemony and the pax Romana throughout the entire world. ${ }^{59}$ The Augustus of Prima

${ }^{57}$ Dio 54. 8. 1-3. Note also Strabo 6. 4. 2; 16. 1. 28; Vell. Pat. 2. 91. 1; Suet. Tib. 9. 1; Eutrop. 7. 9; Orosius 6. 21.

${ }^{58}$ Discovered in 1863 in the Villa of Livia at Prima Porta, most scholars believe the statue is a posthumous copy of a bronze original, ca. 20 BCE. Either Augustus' wife, Livia, or his successor, Tiberius, likely commissioned the copy after Augustus' death since, although he is portrayed in military dress, he has the bare feet of a god instead of military boots. It also is unclear if the details of the breastplate accompanied the bronze original or were a later addition. Note WoODFORD, S.: The Art of Greece and Rome. Cambridge 1982, 85; ZAnKer, P.: The Power of Images in the Age of Augustus. Trans. A. Shapiro. Ann Arbor 1988, 188; KLEInER, F. S.: A History of Roman Art. Boston 2010, 68-69.

${ }^{59}$ Note FitTschen, K.: Die Bildnisse des Augustus. In BINDER, G. (ed.): Saeculum Augustum III: Kunst und Bildersprache. Darmstadt 1991, 149-186; Simon, E.: Altes und Neues zur Statue des Augustus von Primaporta. In Saeculum Augustum III, 204-233; Boschung, D.: Die Bildnisse des Augustus, Das römische Herrscherbild I . Berlin 1993, 179-181; RosE, C. B.: The Parthians in Augustan Rome. American Journal of Archaeology 109 (2005) 21-75; SQUIRE, M.: Embodied ambiguities on the Prima Porta Augustus. Art History 36.2 (2013) 242-279. For Augustus and the rhetoric of imperial peace, see FUHRMAnN, C. J.: Policing the Roman Empire: Soldiers, Administration, and Public Order. Oxford 2012, ch. 4. 
Porta is only one example of a much wider artistic and literary effort during the Augustan Age to utilize imperial propaganda to shape the imagery of the Parthians in order to mask Rome's lack of military success in the East and the limits of its hegemony. ${ }^{60}$

An important part of this propagandistic imperial message was the humiliating failure of Crassus. Augustan Age writers helped reinforce the image of Augustus' triumph by portraying Crassus negatively. Quintus Dellius, who had been a subordinate of Cassius and Mark Antony but who betrayed Antony before the Battle of Actium and forged a close relationship with Augustus, wrote a history on the Romano-Parthian conflict during Augustus' reign that became an important source for later writers, such as Strabo and Plutarch. ${ }^{61}$ From Dellius' background and from the tone of Plutarch's narrative, it is highly likely that Dellius was critical of Crassus. Meanwhile, Ovid, Propertius, and Horace found Crassus' defeat disgraceful. ${ }^{62}$ Virgil longed for the Romans "to reclaim their standards from the Parthian [king]". ${ }^{63}$ Moreover, Ovid writes, "But lo, Caesar [Augustus] makes ready to complete the conquest of the world! Ye far-off countries of the East, to our laws shall ye submit; and you, ye arrogant Parthians, shall be punished as ye deserve. Rejoice, shades of Crassus, and you, ye Roman Eagles, ashamed at your long sojourn in barbarian hands, be of good cheer, your avenger is at hand." 64 Unsurprisingly, an emphasis of the Augustan Age poets is that Augustus would finally right the wrong of Crassus.

The Roman writers who followed shared similar feelings of embarrassment, frustration, and anger toward Crassus. Lucan, writing in the middle of the first century CE, blamed Crassus for seeking the Parthian war against the will of Rome. ${ }^{65} \mathrm{He}$ also blamed Crassus' death for the civil war between Caesar and Pompey. ${ }^{66}$ He states,

Concord, on discord based, brief time endured, unwelcome to the rivals; and alone Crassus delayed the advent of the war. Like to the slender neck that separates the seas of Graecia: should it be engulfed then would the Ionian and Aegean mains break each on other: thus when Crassus fell, who held apart the chiefs [that is, Caesar and Pompey], in piteous death, and stained Assyria's plains with Latin blood, defeat in Parthia loosed the war in Rome. More in that victory than ye thought was won, ye sons of Arsaces [the Parthians]; your conquered foes took at your hands the rage of civil strife. The mighty realm that earth and sea contained, to which all peoples bowed, split by the sword, could not find space for two [leaders]. ${ }^{67}$

${ }^{60}$ Note SchneIder, R. M.: Friend and Foe: The Orient in Rome. In Curtis, V. S. - Stewart, S.: The Age of the Parthians. Vol. 2: The Idea of Iran. London 2007, 50-86.

${ }^{61}$ Strabo 11. 13. 3; Plut. Ant. 25, 59; Dio 49. 39; 50. 13. 8, 23; Jos. Ant. 14. 394; Jos. Bell. 1. 290; Sen. Suas. 1. 7; Sen. Clem. 1. 10. 1. Note also AdCocK, F. E.: Marcus Crassus, Millionaire. Cambridge 1966, 59; SAMPSON (n. 3) 189.

${ }^{62}$ Ovid Fasti 5. 583-585; Prop. 2. 10. 13-14; 4. 7. 83-85; Hor. Odes 3. 5. 5-12.

${ }^{63}$ Virg. Aen. 7. 601-606.

${ }^{64}$ Ovid Ars Am. 1. 177-181.

${ }^{65}$ Lucan Phar. 3. 126.

${ }^{66}$ Note also Plut. Pomp. 53. 6-7; Plut. Caes. 28. 1; Orosius 6. 14.

${ }^{67}$ Lucan Phar. 1. 98-114. See also Lucan. Phar. 3. 265. 
Lucan was in fact so unwilling to accept the humiliation of Crassus' defeat and the reluctance of the Romans to punish the Parthians that he criticized Caesar and Pompey for fighting each other instead of avenging the defeat at Carrhae. ${ }^{68}$ Lucan writes with frustration,

And the fates may seem to smile on Parthia; for the spouse of [Publius] Crassus [that is, Cornelia, whom then married Pompey], captive, shall to him [Orodes II] be brought [by Pompey, who considered fleeing to Parthia after Pharsalus in $48 \mathrm{BCE}$ ] as spoil of former conquest. If the wound dealt in that fell defeat in eastern lands still stirs thy heart, then double is the shame first to have waged the war upon ourselves, then ask the foe for succor. For what blame can rest on thee or Caesar worse than this, that in the clash of conflict ye forgot for Crassus' slaughtered troops the vengeance due? First, united should Rome have poured her captains [Pompey and Caesar] upon the Mede [that is, Orodes II], and [been joined by] the [Roman] troops who guard the northern frontier from the Dacian hordes; and all her legions should have left the Rhine free to the Teutons [that is, the Germanic tribes], till the Parthian dead were piled in heaps upon the sands that hide our heroes slain; and haughty Babylon lay at her victor's feet. To this foul peace [of Augustus] we pray an end; and if Thessalia's day [that is, the Battle of Pharsalus] has closed our [civil] warfare, let the conqueror [Caesar] march straight on our Parthian foe. Then should this heart, [and] then only, leap at Caesar's triumph won. Go thou and pass Araxes' chilly stream on this thine errand; and the mournful [Roman] ghost pierced by the Scythian shaft [that is, Parthian arrows] shall greet thee thus: 'Dost thou, to whom our wandering shades have looked for vengeance and for war, seek from the foe a treaty and a peace?' And there profuse shall meet thee sad memorials of the rout: Red is yon wall where passed their headless trunks; Euphrates here engulfed them, Tigris there cast up to perish. Gaze on such array, and thou canst supplicate at Caesar's feet in mid Thessalia seated. ${ }^{69}$

Thus, Lucan contended quite passionately that Rome should have avoided civil war and ignored all other enemies of the Roman state in order to strike at the Parthians with the full might of the Roman army and, through slaughter and conquest, regained Rome's

${ }^{68}$ Lucan Phar. 1. 11; 2. 526-554; 7. 431; 8. 91, 302, 327, 358, 394.

${ }^{69}$ Lucan Phar. 8. 408-441. Note Plut. Pomp. 55. 1-2; 74. 3; 76. 6. 
dignity.$^{70}$ Lucan especially believed it had been Caesar's duty to punish the Parthians..$^{71}$ Lucan interestingly even chastises Augustus' peace with Parthia and demonstrates that some Romans found Augustus' nonviolent settlement with the Parthians unacceptable.

In the post-Carrhae world, many Romans wanted someone to avenge Crassus' defeat and thought this mission was important. Yet since Caesar died just before leaving Rome to fight the Parthians, since Antony's Parthian campaign also was a disaster, and since Augustus and his immediate successors avoided hegemonic war against Parthia, later Romans had to exaggerate earlier Roman efforts against the Parthians and to praise Roman "heroes" for punishing the Parthians. ${ }^{72}$ This helped create and sustain the tradition about Cassius becoming a savior hero in the late 50s BCE; however, it also established Ventidius as a savior hero for his defense of Syria in the late 40s and early 30s BCE. In fact, Pliny the Elder claims, "Fortune was pleased that P. Ventidius alone should triumph over the Parthians", and almost the entire literary tradition about these events agreed. ${ }^{73}$

The importance of establishing Roman strength in the East and avenging military setbacks remained a major priority throughout the imperial period. Late antique writers continued to praise emperors who avenged Roman military failures in the East. For example, a Roman biographer of Severus Alexander records that the emperor told the senate,

'We have captured many of the Persians and have sold them into slavery, and we have reconquered the lands which lie between the rivers [that is, the Euphrates and Tigris], those of Mesopotamia I mean, abandoned by that filthy monster [Elagabalus]. Artaxerxes [that is, Ardashir I], the most

${ }^{70}$ Dio records that during Augustus' reign the conflict with Parthia overshadowed concerns with the Germanic tribes. Dio 55. 10a. 3. Meanwhile, Tacitus, who had a clear rhetorical incentive to exaggerate the threat of the Germanic tribes to Rome, argues that the Germans were a more worrisome and fearsome enemy than the Parthians because "German independence truly is fiercer than the despotism of an Arsaces". Tac. Germ. 37. See also Tac. Ann. 13. 54.

${ }^{71}$ Justin records that the Parthians believed Caesar planned to avenge Crassus. He states, "Not long after these occurrences the civil war among the Romans, between Caesar and Pompeius, broke out, in which the Parthians took the side of Pompeius, both from the friendship that they had formed with him in the Mithridatic war, and because of the death of Crassus, whose son they understood to be of Caesar's party, and supposed that, if Caesar were victorious, he would avenge his father's fate." Justin 42. 4. 6.

72 Dio states, "But while Caesar was thus engaged, a longing came over all the Romans alike to avenge Crassus and those who had perished with him, and they felt some hope of subjugating the Parthians then, if ever. They unanimously voted the command of the war to Caesar, and made ample provision for it." Dio 43. 51. 1. Appian records, "[Caesar] conceived the idea of a long campaign against the Getae and the Parthians. The Getae, a hardy, warlike, and neighboring nation, were to be attacked first. The Parthians were to be punished for their perfidy toward Crassus. He sent across the Adriatic in advance sixteen legions of foot and 10,000 horse." Appian BC 2. 110. Appian also argues that it was Antony's duty to avenge Crassus. Appian. BC 5. 65. See also Dio 49. 24. 5. Antony tried to demand the lost standards and captured soldiers of Crassus back from the Parthians. Plut. Ant. 37. 1-3. Note also Plut. Ant. 46. 3-4.

${ }^{73}$ Pliny NH 7. 43. 135; Justin 42. 4. 7-10; Vell. Pat. 2. 78. 1; Plut. Ant. 33. 4; 34. 1-5; Dio 43. 4-5; 49. 19-21; Tac. Hist. 5. 9; Tac. Germ. 37; Strabo 16. 2. 8; Jos. Bell. 1. 288-291, 309, 317; Jos. Ant. 14. 392-395, 434; Florus 2. 19. 5-7; Livy Epit. 127. 4; 128. 2; Ruf. Fest. 18; Eutrop. 7. 5; Sid. Carm. 2. 453-457; Orosius 6. 18; Juv. 7. 199-200. 
powerful of kings, in fact as well as in name, we have routed and driven from the field, so that the land of the Persians saw him in full flight, and where once our ensigns were led away in triumph, there the king himself fled apace leaving his own standards. ${ }^{74}$

Although this is undeniably propaganda, here the Roman message was that Severus Alexander too had helped alleviate the stain of Crassus' failure, which had remained a point of concern for centuries.

Carrhae quickly became a Roman literary trigger that elicited the image of Crassus' failure and the disgrace that it brought upon the Roman state. For instance, Pliny the Elder in his description of the cities near the Euphrates refers to the city as "Carrhae, notorious for the disaster of Crassus" ${ }^{75}$ Pliny illustrates that later Romans associated Carrhae directly with Crassus' defeat. Therefore, Roman writers understood well what image the mention of Carrhae would provoke in their reader. In fact, the embarrassing Roman defeat at Carrhae remained so iconic even in late antiquity that authors often associated the city with later Roman invasions of Mesopotamia. For instance, there is a propagandistic account of Emperor Gordian III winning repeated battles against the Sassanid Persians, taking Carrhae, and establishing Roman dominance in the East. ${ }^{76}$ Another account states, "Now at once he [Saturninus Odaenathus, king of the Palmyrenes] proclaimed a war on the [Sassanid] Persians to exact for Valerian the vengeance neglected by Valerian's son. He immediately occupied Nisibis and Carrhae, the people of which surrendered, reviling Gallienus." ${ }^{\prime 77}$ Here the author criticizes Gallienus for his failure to avenge his father and the reputation of Rome. Instead, in this passage an eastern rival of Gallienus brings further shame upon Gallienus by avenging the defeat of Valerian and indirectly, through the mention of the conquest of Carrhae, the defeat of Crassus. ${ }^{78}$ Note also that immediately preceding this passage the author criticizes the ridiculousness of a triumph of Gallienus, which featured men dressed as Persian captives in order to fool the crowd. The author records,

One well-known instance of jesting, however, must not be omitted. As a band of Persians, supposed to be captives, was being led along in the procession (such an absurdity!), certain wits mingled with them and most carefully scrutinized all, examining with open-mouthed astonishment the features of every one; and when asked what they meant by that sagacious investigation, they replied, 'We are searching for the Emperor's father [Valerian]. ${ }^{79}$

${ }^{74}$ HA Sev. Alex. 56. 5-7 (italics are mine).

${ }^{75}$ Pliny NH 5. 21. 86.

${ }^{76}$ HA Gord. 26.

${ }^{77}$ HA Gall. 10. 1-3. See also HA Gall. 12-13. Aurelian also was praised for avenging the defeat of Valerian. HA Aurel. 41. 9.

${ }^{78}$ Rufus Festus also criticizes Gallienus for his inaction, calls it "shameful" that Odaenathus had to defeat the Persians, and labels Odaenathus an "avenger of Roman imperium" for his victories. Ruf. Fest. 23. 2. Note also Eutrop. 9. 10.

${ }^{79}$ HA Gall. 7. 4 - 9. 8. 
The shameful defeat of Valerian, like the original disgrace of Crassus, grabbed the attention of Roman writers and audiences, who desired Rome's emperors to avenge these military embarrassments in the East by force of arms. ${ }^{80}$

Finally, the Gallic bishop Sidonius Apollinaris, writing in the fifth century CE as the Western Roman Empire crumbled, offers an interesting late antique Roman perspective on the disaster of Crassus and its implications for later Romans. In his panegyric on Anthemius, Sidonius created a dialogue between the goddesses Aurora and Roma. Sidonius has Roma assure Aurora that she has not returned to the East to conquer Armenia or the entire Parthian Empire. ${ }^{81}$ Roma continues, "All that lies between the Euphrates and Tigris thou hast long possessed alone; yet that possession was bought by me with the blood of Crassus; at Carrhae I paid down the price; nor did I remain unavenged nor lose the land thus bought; if my word is not good, Sapor [that is, Pacorus, son of Orodes II] hath proved it, slain by Ventidius." 82 Sidonius here has the embodiment of Rome argue that Crassus' defeat purchased northern Mesopotamia for the Romans with blood and that his death required retaliation. Sidonius, following an over five-centuries-long propagandistic tradition, praises Ventidius for avenging Crassus' defeat at Carrhae.

\section{FINAL THOUGHTS}

The disaster at Carrhae scarred the Roman psyche and severely damaged the Roman ego. The memory of Crassus' defeat and the frustration it elicited hung over the Roman consciousness for centuries, affecting much, if not all, of what the Roman tradition said about the Parthians as an eastern power and rival. Further, the Romans never forgave the embarrassing failure of Crassus against the Parthians. Roman writers universally placed all blame on Crassus for the defeat at Carrhae in an attempt to exonerate the Roman state from this catastrophe. Yet Crassus is a much maligned historical figure and victim of character assassination by later Roman writers. The Romans could neither accept the humiliation of the defeat at Carrhae, nor admit that the Parthians had earned their victory through military superiority. Instead, a widely accepted tradition of anti-Crassus propaganda emerged that ignored the geopolitical realities that led to the conflict, blamed Crassus' greed for the disaster at Carrhae, and labeled him as an infamous example of unbridled Roman aggression, impiety, and military foolishness.

Undoubtedly, Crassus' campaign was a catastrophe, and Crassus had an important part to play in this; however, we must place greater emphasis on the crucial role that the Parthians played in these events and stop blaming the defeat primarily on the alleged avarice or ineptitude of Crassus. Although the Romans clearly had several good reasons to distance themselves from the disaster at Carrhae, the seemingly universal bias of the sources against Crassus unfortunately still in many ways dominates our

\footnotetext{
${ }^{80}$ Rufus Festus calls Valerian's defeat “disgusting”. Ruf. Fest. 23. 1.

${ }^{81}$ Sid. Carm. 2. 436-452.

${ }^{82}$ Sid. Carm. 2. 453-457. See also Sid. Carm. 9. 250-252.
} 
understanding of Crassus' image and legacy and the contexts of the First Romano-Parthian War. Crassus' demise lies at the center of one of the most popular and enduring of Roman literary traditions, and his name became synonymous with Roman defeat in the East.

Nikolaus Leo Overtoom

Department of History

University of New Mexico

USA 